Zeszyty Naukowe Szkoły Głównej Gospodarstwa Wiejskiego w Warszawie Problemy Rolnictwa Światowego tom 17 (XXXII), zeszyt 2, 2017: 224-233

DOI: 10.22630/PRS.2017.17.2.41

Tomasz Rokicki', Magdalena Golonko²

Szkoła Główna Gospodarstwa Wiejskiego w Warszawie

\title{
Handel zagraniczny ziołami i przyprawami na świecie
}

\section{Foreign Trade of Herbs and Spices in the World}

\begin{abstract}
Synopsis. Celem głównym badań była ocena zmienności handlu zagranicznego ziołami i przyprawami na świecie i próba wskazania występujących prawidłowości. W artykule przedstawiono wartość eksportu i importu ziół i przypraw w USD w państwach z top-20. Źródłem materiałów były dane z FAOSTAT. Okres badań dotyczył lat 2007-2015. W badanym okresie handel zagraniczny ziołami i przyprawami na świecie znacząco zwiększył się. Wartość eksportu i importu w 2015 roku był na podobnym poziomie około 2,2-2,4 mld USD. Największymi eksporterami ziół i przypraw były Chiny i Indie, zaś importerami USA i Arabia Saudyjska. Najwięcej spadków w eksporcie ziół i przypraw stwierdzono w latach 2009-2010, a w imporcie w 2009 roku. W przypadku państw o największym eksporcie zmiany w poszczególnych latach były gwałtowne, zaś w przypadku importu umiarkowane. W badanym okresie stwierdzono istotny bardzo silny dodatni związek importu ziół i przyprawa z parametrami gospodarki określonymi przez wartość PKB, wartość eksportu oraz importu, zaś przeciętny i słaby w odniesieniu do eksportu ziół i przypraw (ale tylko po wyjściu z kryzysu gospodarczego).
\end{abstract}

Słowa kluczowe: zioła, przyprawy, handel na świecie, eksport, import

Abstract. The aim of the study was to evaluate the variability of the foreign trade herbs and spices in the world and attempt to identify common patterns. The article presents the value of export and import of herbs and spices in US dollars in top-20 countries. The source materials constituted data of FAOSTAT. The study period covered the 2007-2015. In 2007-2015, foreign trade herbs and spices in the world has increased. The value of exports and imports in 2015 was at a similar level of around 2.22.4 billion USD. The largest exporters of herbs and spices were China and India, while the importers were USA and Saudi Arabia. The greatest decline in herbs and spices exports was recorded in 20092010, and in imports in 2009. In the case of countries with the largest exports of changes in individual years they were violent, and in the case of imports moderate. During the period considered important, very strong, positive relationship of herbs and spice imports with economic parameters determined by the GDP value, the value of exports and imports, and the average and weak with reference to exports of herbs and spices (but only after coming out of the economic crisis).

Key words: herbs, spices, trade in world, export, import

\section{Wprowadzenie}

Zioła i przyprawy były znane już od zarania dziejów. Ludzie pierwotni stosowali je w celu poprawy smaku mięsa upolowanej zwierzyny. W zapiskach sumeryjskich, egipskich czy chińskich, pojawiły się pierwsze nazwy przypraw wraz ze wskazaniem ich użycia (Stelmach, 2017). Potwierdzeniem stanu ówczesnej wiedzy był napisany około $1550 \mathrm{r}$.

\footnotetext{
${ }^{1}$ dr inż., Katedra Logistyki SGGW, ul. Nowoursynowska 166, 02-787 Warszawa,

e mail: tomasz_rokicki@sggw.pl

2 mgr, Katedra Logistyki SGGW, ul. Nowoursynowska 166, 02-787 Warszawa,

e-mail: magdalena_wiluk@sggw.pl
} 
p.n.e. tzw. papirus Ebersa, zawierający liczne recepty z opisem składników oraz sposobem przyrządzania leków. Mieszkańcy Indii posiadali szeroką wiedzę o ziołach i przyprawach korzennych, które w dalszej kolejności trafiały na rynki europejskie, a były wśród nich: imbir, kardamon, pieprz, olej sezamowy czy gałka muszkatołowa (Iwaniuk, 2006). Ogromny wpływ na rozwój zielarstwa miało odkrycie w 1492 roku Ameryki przez Krzysztofa Kolumba oraz znalezienie nowej drogi do Indii w 1498 roku przez Vasco da Gama. Powiększyło to znacznie asortyment roślin, a także umożliwiło import licznych przypraw korzennych i roślin zielarskich z Indii i Chin (Sederski, 2009). Posiadanie przypraw z odległych krajów, było niegdyś wyznacznikiem dobrobytu i bardzo cennym towarem wymiany podczas wojen (Stelmach, 2017).

W Polsce także wykorzystywano zioła i przyprawy od najdawniejszych czasów. Około 350 lat p.n.e. znane były zarówno rośliny o działaniu odżywczym, jak i leczniczym, tj.: kozłek lekarski, dziurawiec, dziewanna, rdest ptasi, rzepik pospolity, jałowiec. $\mathrm{W}$ średniowieczu nastąpił największy rozwój zielarstwa wraz z przyjazdem do Polski Benedyktynów, którzy przywieźli ze sobą rośliny pochodzenia śródziemnomorskiego. Rośliny $\mathrm{z}$ basenu morza śródziemnego, uprawiane $\mathrm{w}$ zakonach nie posiadały polskiego nazewnictwa, a jedynie spolszczone łacińskie nazwy, tj. tymianek (Thymi), melisa (Melisa), szałwia (Salvia), rozmaryn (Rosmarinus) i inne (Sederski, 2009).

Polska jest krajem o dużych możliwościach produkcyjnych oraz przetwórczych wysokiej jakości surowca. Na terenie kraju występuje ok. 2500 gatunków roślin, z których przemysł zielarski wykorzystuje ok. 170, pochodzacych z upraw polowych oraz stanu naturalnego (Seidler-Łożykowska, 2009). Wiele gatunków roślin zielarskich znalazło zastosowanie również jako przyprawy, a ich właściwości aromatyczne oraz lecznicze wpływają korzystnie na proces trawienia i przyswajania składników pokarmowych (Nurzyńska-Wierdak, 2012).

Obecnie rośliny zielarskie: zioła oraz zioła przyprawowe mają szerokie zastosowanie i są wykorzystywane $\mathrm{w}$ farmacji, kosmetologii, kulinariach a także w rolnictwie jako składniki pasz i nawozy zielone. Największa konsumpcja przypraw ziołowych występuje w Azji, a krajami wiodącymi są Indie, Chiny i Tajlandia. W USA i rozwiniętych krajach europejskich obserwuje się wzrost spożycia przypraw, na co wpływ miały zmieniające się nawyki żywieniowe konsumentów oraz wzrost popularności potraw etnicznych i pikantnych (Williams, 2006).

W Polsce uprawa roślin zielarskich obejmuje powierzchnię ponad 14 tys. ha, co tym samym daje nam miejsce $\mathrm{w}$ czołówce europejskich producentów owego surowca. Porównując powierzchnię zasiewów ziół i przypraw do ogólnej powierzchni zasiewów ich uprawa to jedynie niewielki odsetek produkcji roślinnej (Sadowski, Kozłowska-Burdziak, 2013). Polowa uprawa surowców może stanowić istotne źródło dochodu gospodarstw rolnych, pod warunkiem ciagłego dostosowywania się do zmieniającego się popytu, cen oraz potrzeb klienta (Hołubowicz-Kliza, 2012).

Rynek przypraw dzieli się na dwie kategorie: przyprawy sypkie oraz przyprawy płynne. Do pierwszej z nich zalicza się przyprawy jednoskładnikowe, mieszanki przypraw przygotowane do konkretnych potraw, przyprawy uniwersalne, które są połączeniem soli z suszonymi warzywami oraz zawierające substancje wzmacniające zapach i smak potraw. Do drugiej grupy jaką są przyprawy płynne zalicza się zupy oraz sosy. Statystycznie, jak podaje GUS, spośród kategorii przypraw i dodatków do żywności największą część stanowi ocet i musztarda (37\%), majonez i dressingi (24\%), przyprawy (19\%), ketchup (16\%) oraz sosy (4\%). Rynek przypraw i dodatków do żywności szacowany jest na ok. 1 mld zł 
według danych GUS (UOKiK, 2007). W Polsce w 2013 roku liczba przedsiębiorstw zajmujących się produkcją przypraw wynosiła 284 i zwiększyła się o 11,8\% w latach 20092013 (Olewnicki, 2015).

W celu stworzenia produktów finalnych, jakie trafiają na sklepowe półki, niezbędne jest wykorzystanie licznych gatunków roślin pochodzących z całego świata. W związku z tym konieczny jest import i eksport surowców do rejonów, gdzie nie są uprawiane dane gatunki roślin. W latach $2007-2015$ według danych FAO odnotowano wzrost wartości eksportu ziół i przypraw w krajach UE na poziomie 109,8\% oraz importu o 109,0\%. Przedsiębiorstwa działające na polskim rynku ziół i przypraw nie zaobserwowały możliwych do wystąpienia barier $\mathrm{w}$ eksporcie i imporcie surowców zielarskich. W badanym okresie wystapił kryzys gospodarczy na świecie. W Polsce zaobserwowano raptowny spadek wartości PKB z 2,9\% w IV kwartale 2008 roku do 0,8\% w I kwartale 2009 roku, jednak według danych FAO na rynku ziół i przypraw zanotowano wzrost dynamik importu aż w czternastu europejskich krajach (NBP, 2009).

\section{Materiał i metodyka badań}

Celem głównym badań była ocena zmienności handlu zagranicznego ziołami i przyprawami na świecie oraz próba wskazania występujących prawidłowości. Celami szczegółowymi było przedstawienie zmian w eksporcie i imporcie ziół oraz przypraw w latach 2007-2015, wskazanie okresów $\mathrm{z}$ najwyższym i najniższym handlem zagranicznym, określenie prawidłowości, które występują w krajach determinujących wymianę handlową tym towarem, określenie związków eksportu i importu z sytuacją w gospodarce. Do badań przyjęto kraje decydujące o światowym handlu ziołami i przyprawami, czyli o największej jego wartości w zakresie importu i eksportu. Dane dotyczą najważniejszych ziół i przypraw. Były to: imbir, szafran, kurkuma, tymianek, liście laurowe, curry i inne zioła i przyprawy, ale z wyłączeniem pieprzu rodzaju Piper, owoców rodzaju Capsicum lub rodzaju Pimenta, wanilii, cynamonu, kwiatów cynamonowych, goździków, gałki muszkatołowej, koronki, kardamonu, nasiona anyżu, badian, kopru włoskiego, kolendry, kminku oraz jagód jałowca. Źródła materiałów stanowią dane FAOSTAT-u. Okres badawczy obejmował lata 2007-2015. W pracy wykorzystano metode opisową i porównawczą, posługiwano się wskaźnikami dynamiki i obliczono współczynnik korelacji liniowej Pearsona.

\section{Wyniki badań}

Wartość eksportu ziół i przypraw na świecie, mierzona w cenach bieżących, zwiększyła się w latach 2007-2015 o 109,8\%, zaś importu o 109,0\%. W 2015 roku łącznie wyeksportowano zioła i przyprawy o wartości 2,24 mld USD, zaś import wyniósł 2,39 mld USD. Występowała więc niewielka nadwyżka importu nad eksportem w bilansie handlowym. W przypadku ziół i przypraw istnieje ich duża różnorodność oraz występują duże różnice $\mathrm{w}$ wartości pieniężnej. $\mathrm{W}$ badanym okresie mogła zmienić się struktura produktów, jednak w pracy nie bada się takich zależności, gdyż analizie podlega łączna wartość ziół i przypraw. 
Wśród największych eksporterów były państwa azjatyckie i europejskie, o różnym poziomie rozwoju gospodarczego (rys. 1). Liderem były Chiny, które zwiększyły zdecydowanie sprzedaż poza granice kraju z 183 mln USD w 2007 roku do $483 \mathrm{mln}$ USD. Eksport z tego państwa stanowił w 2015 roku około $22 \%$ całej sprzedaży na świecie. Należy dodać, że w latach 2007-2015 wartość eksportu ziół i przypraw w Chinach wzrosła o 164\%, przy czym były okresy, w których następował spadek, jak lata 2011-2012 i 2015. Eksport $\mathrm{z}$ top 5 krajów świata $\mathrm{w} 2007$ roku stanowił 1/2 obrotów światowych. Po ośmiu latach udział ten nieznacznie wzrósł do 55\%, głównie za sprawą Chin i Indii.

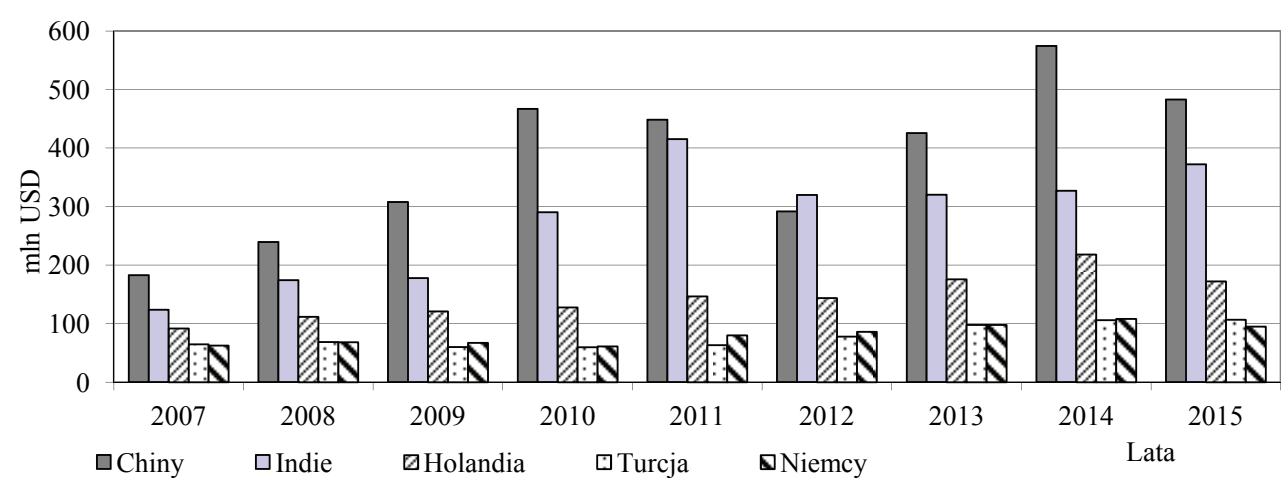

Rys. 1. Najwięksi eksporterzy ziół i przypraw na świecie w latach 2007-2015 (mln USD)

Fig. 1. The largest exporters of herbs and spices in the world in 2007-2015 (million USD)

Źródło: opracowanie własne na podstawie danych FAOSTAT.

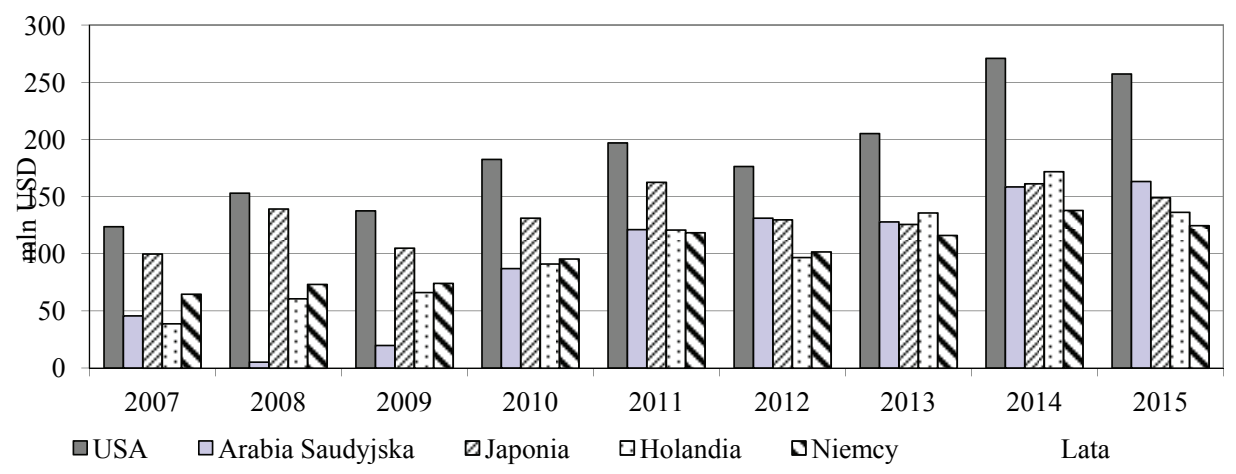

Rys. 2. Najwięksi importerzy ziół i przypraw na świecie w latach 2007-2015 (mln USD)

Fig. 2. The largest importers of herbs and spices in the world in 2007-2013 (million USD)

Źródło: jak na rys. 1.

W przypadku importu ziół i przypraw pierwsza piątka państw była inna, niż dla eksportu, chociaż powtórzyły się Niemcy i Holandia (rys. 2). Największym importerem ziół i przypraw na świecie były Stany Zjednoczone Ameryki. W USA zakupiono w 2015 roku zioła i przyprawy o wartości $257 \mathrm{mln}$ USD, co stanowiło około $11 \%$ światowego importu. Taki sam udział tego kraju odnotowano też w 2007 roku. W 2015 roku pierwsza piątka 
państw realizowała 35\% wartości importu ziół i przypraw na świecie. W 2007 roku koncentracja była mniejsza (32,6\%). Można zauważyć, że wszystkie czołowe państwa zwiększyły znacząco import.

W latach 2007-2015 najwięksi eksporterzy i importerzy ziół i przypraw z reguły zwiększyli swoje obroty (tab. 1). Wyjątkiem były Iran, Francja i Austria, gdzie nastąpił spadek wartości eksportu. Największe wzrosty wartości eksportu ziół i przypraw zaobserwowano w Peru (wzrost o 1705,14\%), zaś w przypadku importu w Bangladeszu (wzrost o 336,27\%). Ogólnie w pierwszej dwudziestce było dziewięć państw o dynamice wzrostu eksportu przewyższającej 100\% i dziewięć analogicznie w zakresie importu.

Tabela 1. Wskaźniki dynamiki o podstawie stałej dla największych eksporterów i importerów ziół i przypraw na świecie w latach 2007-2015 (2007 rok = 100)

Table 1. Changes in export and import of herbs and spices in the world in 2007-2015 (2007 years $=100)$

\begin{tabular}{|c|c|c|c|c|}
\hline \multirow{3}{*}{ Lokata } & \multicolumn{4}{|c|}{ Wskaźniki dynamiki o podstawie stałej dla 2015 roku $(2007=100)$} \\
\hline & \multicolumn{2}{|c|}{ Eksport } & \multicolumn{2}{|c|}{ Import } \\
\hline & kraj & wskaźnik & kraj & wskaźnik \\
\hline 1. & Chiny & 263,97 & USA & 208,24 \\
\hline 2. & Indie & 301,21 & Arabia Saudyjska & 357,89 \\
\hline 3. & Holandia & 187,53 & Japonia & 149,18 \\
\hline 4. & Turcja & 165,06 & Holandia & 350,94 \\
\hline 5. & Niemcy & 151,55 & Niemcy & 192,54 \\
\hline 6. & Iran & 31,16 & Wielka Brytania & 206,23 \\
\hline 7. & Hiszpania & 146,72 & Zjednoczone Emiraty Arabskie & 281,27 \\
\hline 8. & Pakistan & 419,95 & Hiszpania & 165,11 \\
\hline 9. & RPA & 619,09 & Francja & 173,02 \\
\hline 10. & USA & 166,96 & Pakistan & 244,69 \\
\hline 11. & Francja & 67,20 & Kanada & 171,16 \\
\hline 12. & Nigeria & 314,33 & Malezja & 297,91 \\
\hline 13. & Wielka Brytania & 182,26 & Indie & 247,83 \\
\hline 14. & Indonezja & 571,70 & Bangladesz & 436,27 \\
\hline 15. & Tajlandia & 178,02 & Belgia & 118,79 \\
\hline 16. & Peru & 1805,14 & Włochy & 130,12 \\
\hline 17. & Arabia Saudyjska & 757,06 & Singapur & 155,78 \\
\hline 18. & Austria & 76,57 & Dania & 193,20 \\
\hline 19. & Portugalia & 1497,01 & Szwecja & 161,91 \\
\hline 20. & Malezja & 198,98 & Rosja & 199,86 \\
\hline
\end{tabular}

Źródło: jak na rys. 1.

Wskaźniki dynamiki o podstawie stałej nie pokazują zmian, które dokonywały się w poszczególnych latach. W badanym okresie nastapił kryzys gospodarczy, co mogło wpłynąć na dynamikę eksportu i importu. W tabeli 2 przedstawiono wskaźniki dynamiki o podstawie zmiennej dla wartości eksportu. Przy obliczaniu wskaźników przyjęto wartość dla roku poprzedniego za 100. W kryzysowym 2009 roku jedynie w sześciu krajach z top- 
20 odnotowano spadek wartości eksportu. Podobnie było w 2010 roku. W Arabii Saudyjskiej w badanym okresie nie odnotowano eksportu ziół i przypraw. Szczególnie duży spadek wartości eksportu w 2009 roku wystapił we Francji (spadek o 37\%) i Austrii (o 34\%). W latach przed kryzysem gospodarczym i po (od 2011 roku) z reguły w 16-17 państwach wzrastała wartość eksportu, co pokazuje, że rok 2009 wpłynął na eksport ziół i przypraw. Analiza wskaźników pozwala stwierdzić, że skutki kryzysu w eksporcie ziołami i przyprawami, nie były mocno odczuwalne, jak w innych branżach bezpośrednio związanych z gospodarką. U czołowych eksporterów podanych w pierwszych wierszach tabeli zmiany wskaźników z reguły były bardzo gwałtowne. Wśród małych eksporterów z reguły wzrosty w poszczególnych latach wynosiły po kilkanaście lub kilkadziesiąt procent.

Tabela 2. Wskaźniki dynamiki o podstawie zmiennej dla eksporterów ziół i przypraw na świecie w latach 20082015 (rok poprzedni $=100)$

Table 2. Changes in export value of spices in the world in 2008-2015 (previous year $=100$ )

\begin{tabular}{|c|c|c|c|c|c|c|c|c|}
\hline \multirow{2}{*}{ Wyszczególnienie } & \multicolumn{8}{|c|}{ Wskaźniki dynamiki łańcuchowe w latach 2007-2015 (rok poprzedni=100) } \\
\hline & 2008 & 2009 & 2010 & 2011 & 2012 & 2013 & 2014 & 2015 \\
\hline Chiny & 130,9 & 168,3 & 255,3 & 245,1 & 159,5 & 232,6 & 314,1 & 264,0 \\
\hline Indie & 141,1 & 144,0 & 235,1 & 336,2 & 258,8 & 259,1 & 264,6 & 301,2 \\
\hline Holandia & 121,6 & 131,8 & 138,9 & 159,5 & 156,4 & 191,2 & 237,5 & 187,5 \\
\hline Turcja & 106,4 & 92,7 & 92,6 & 97,8 & 120,4 & 151,5 & 163,9 & 165,1 \\
\hline Niemcy & 108,9 & 107,5 & 97,7 & 127,9 & 137,8 & 156,5 & 172,5 & 151,5 \\
\hline Iran & 100,0 & 100,0 & 102,0 & 101,7 & 37,0 & 31,8 & 34,8 & 31,2 \\
\hline Hiszpania & 148,8 & 163,7 & 157,8 & 132,4 & 137,4 & 147,8 & 154,1 & 146,7 \\
\hline Pakistan & 135,2 & 165,0 & 228,0 & 278,0 & 326,0 & 345,8 & 386,7 & 420,0 \\
\hline RPA & 111,4 & 130,5 & 507,2 & 568,2 & 602,3 & 608,9 & 625,9 & 619,1 \\
\hline USA & 124,6 & 119,5 & 136,0 & 142,0 & 149,8 & 154,3 & 159,8 & 167,0 \\
\hline Francja & 89,7 & 63,0 & 63,4 & 67,4 & 59,8 & 63,5 & 75,2 & 67,2 \\
\hline Nigeria & 91,3 & 109,2 & 389,1 & 338,0 & 707,2 & 781,9 & 264,7 & 314,3 \\
\hline Wielka Brytania & 108,2 & 98,2 & 120,3 & 128,6 & 142,9 & 181,3 & 175,3 & 182,3 \\
\hline Indonezja & 148,4 & 185,2 & 296,4 & 219,9 & 140,6 & 368,4 & 922,9 & 571,7 \\
\hline Tajlandia & 158,1 & 150,3 & 173,2 & 164,0 & 138,4 & 204,5 & 242,2 & 178,0 \\
\hline Peru & 186,1 & 192,0 & 530,8 & 567,1 & 446,1 & 810,0 & 2115,7 & 1805,1 \\
\hline Arabia Saudyjska & 0,0 & 0,0 & 185,8 & 264,1 & 407,3 & 389,5 & 694,6 & 757,1 \\
\hline Austria & 64,7 & 65,9 & 58,9 & 57,9 & 58,5 & 61,5 & 80,1 & 76,6 \\
\hline Portugalia & 202,9 & 446,0 & 488,9 & 425,2 & 411,1 & 826,2 & 1301,3 & 1497,0 \\
\hline Malezja & 157,6 & 146,0 & 162,5 & 188,9 & 221,8 & 216,8 & 211,4 & 199,0 \\
\hline Chiny & 130,9 & 168,3 & 255,3 & 245,1 & 159,5 & 232,6 & 314,1 & 264,0 \\
\hline Indie & 141,1 & 144,0 & 235,1 & 336,2 & 258,8 & 259,1 & 264,6 & 301,2 \\
\hline Holandia & 121,6 & 131,8 & 138,9 & 159,5 & 156,4 & 191,2 & 237,5 & 187,5 \\
\hline Turcja & 106,4 & 92,7 & 92,6 & 97,8 & 120,4 & 151,5 & 163,9 & 165,1 \\
\hline Niemcy & 108,9 & 107,5 & 97,7 & 127,9 & 137,8 & 156,5 & 172,5 & 151,5 \\
\hline Iran & 100,0 & 100,0 & 102,0 & 101,7 & 37,0 & 31,8 & 34,8 & 31,2 \\
\hline Hiszpania & 148,8 & 163,7 & 157,8 & 132,4 & 137,4 & 147,8 & 154,1 & 146,7 \\
\hline Pakistan & 135,2 & 165,0 & 228,0 & 278,0 & 326,0 & 345,8 & 386,7 & 420,0 \\
\hline
\end{tabular}

Źródło: jak na rys. 1. 
Tabela 3. Wskaźniki dynamiki o podstawie zmiennej dla importerów ziół i przypraw na świecie w latach 20082015 (rok poprzedni $=100$ )

Table 3. Changes in export value of herbs and spices in the world in 2008-2015 (previous year $=100$ )

\begin{tabular}{|c|c|c|c|c|c|c|c|c|}
\hline \multirow{2}{*}{ Wyszczególnienie } & \multicolumn{8}{|c|}{ Wskaźniki dynamiki łańcuchowe w latach 2008-2015 (rok poprzedni=100) } \\
\hline & 2008 & 2009 & 2010 & 2011 & 2012 & 2013 & 2014 & 2015 \\
\hline USA & 123,8 & 111,2 & 147,7 & 159,3 & 142,7 & 166,0 & 219,3 & 208,2 \\
\hline Arabia Saudyjska & 11,1 & 43,2 & 190,7 & 265,5 & 287,7 & 280,2 & 347,6 & 357,9 \\
\hline Japonia & 139,5 & 105,0 & 131,4 & 162,8 & 129,9 & 125,9 & 161,5 & 149,2 \\
\hline Holandia & 156,4 & 170,2 & 234,7 & 311,1 & 249,2 & 349,6 & 442,8 & 350,9 \\
\hline Niemcy & 113,3 & 114,7 & 147,7 & 183,1 & 157,0 & 179,3 & 213,1 & 192,5 \\
\hline Wielka Brytania & 127,3 & 134,4 & 170,5 & 175,4 & 149,3 & 179,3 & 236,3 & 206,2 \\
\hline $\begin{array}{l}\text { Zjednoczone Emiraty } \\
\text { Arabskie }\end{array}$ & 140,1 & 154,0 & 172,1 & 187,2 & 204,8 & 217,1 & 272,7 & 281,3 \\
\hline Hiszpania & 158,0 & 174,5 & 153,3 & 130,2 & 125,7 & 126,4 & 144,5 & 165,1 \\
\hline Francja & 151,7 & 151,7 & 169,6 & 185,4 & 151,4 & 166,3 & 205,6 & 173,0 \\
\hline Pakistan & 122,5 & 131,7 & 176,4 & 192,1 & 84,3 & 134,7 & 181,7 & 244,7 \\
\hline Kanada & 125,4 & 111,9 & 140,1 & 136,7 & 123,4 & 162,6 & 217,1 & 171,2 \\
\hline Malezja & 135,2 & 174,0 & 310,9 & 263,6 & 195,8 & 292,4 & 371,5 & 297,9 \\
\hline Indie & 107,0 & 116,0 & 157,7 & 151,6 & 123,2 & 157,6 & 210,7 & 247,8 \\
\hline Bangladesz & 125,3 & 209,8 & 314,2 & 403,5 & 308,6 & 459,1 & 411,4 & 436,3 \\
\hline Belgia & 106,9 & 95,1 & 87,3 & 104,6 & 100,2 & 135,6 & 137,1 & 118,8 \\
\hline Włochy & 150,4 & 196,1 & 165,8 & 133,6 & 108,6 & 120,0 & 137,2 & 130,1 \\
\hline Singapur & 131,6 & 118,0 & 146,3 & 135,9 & 126,3 & 150,8 & 188,2 & 155,8 \\
\hline Dania & 122,3 & 144,3 & 140,3 & 148,8 & 172,9 & 196,1 & 229,3 & 193,2 \\
\hline Szwecja & 128,8 & 153,6 & 126,0 & 144,6 & 141,8 & 146,5 & 167,3 & 161,9 \\
\hline Rosja & 62,6 & 73,5 & 102,3 & 114,6 & 222,2 & 233,7 & 228,0 & 199,9 \\
\hline USA & 123,8 & 111,2 & 147,7 & 159,3 & 142,7 & 166,0 & 219,3 & 208,2 \\
\hline Arabia Saudyjska & 11,1 & 43,2 & 190,7 & 265,5 & 287,7 & 280,2 & 347,6 & 357,9 \\
\hline Japonia & 139,5 & 105,0 & 131,4 & 162,8 & 129,9 & 125,9 & 161,5 & 149,2 \\
\hline Holandia & 156,4 & 170,2 & 234,7 & 311,1 & 249,2 & 349,6 & 442,8 & 350,9 \\
\hline Niemcy & 113,3 & 114,7 & 147,7 & 183,1 & 157,0 & 179,3 & 213,1 & 192,5 \\
\hline Wielka Brytania & 127,3 & 134,4 & 170,5 & 175,4 & 149,3 & 179,3 & 236,3 & 206,2 \\
\hline $\begin{array}{l}\text { Zjednoczone Emiraty } \\
\text { Arabskie }\end{array}$ & 140,1 & 154,0 & 172,1 & 187,2 & 204,8 & 217,1 & 272,7 & 281,3 \\
\hline Hiszpania & 158,0 & 174,5 & 153,3 & 130,2 & 125,7 & 126,4 & 144,5 & 165,1 \\
\hline
\end{tabular}

Źródło: jak na rys. 1.

Na wartość importu ziół i przypraw również wpływała sytuacja gospodarcza na świecie i w poszczególnych krajach, choć siła oddziaływania była mniejsza niż przy eksporcie. Przedstawione wskaźniki dynamiki o podstawie zmiennej pozwalają wskazać na gorsze i lepsze okresy dla importerów z danego kraju (tab. 3). Kryzysowy 2009 rok nie był zły, gdyż $\mathrm{w}$ trzech państwach $\mathrm{z}$ top-20 zanotowano spadek dynamik importu. Były to Arabia Saudyjska (spadek o 57\%), Rosja (o 26,5\%) i Belgia (5\%). Od 2013 roku wszyscy 
najwięksi importerzy zwiększali swoje obrotu. Wydaje się, że na import mniejszy wpływ miała sytuacja gospodarcza $\mathrm{w}$ danym kraju, niż na eksport.

W celu stwierdzenia związku zmian wartości eksportu oraz importu ziół i przypraw na świecie z gospodarką zostały obliczone współczynniki korelacji liniowej Pearsona (tab. 4). Jako wartość graniczną poziomu istotności przyjęto $\mathrm{p}=0,05$. Istotne wyniki zostały oznaczone szarym tłem $w$ tabeli. Współczynniki korelacji zostały policzone indywidualnie dla okresu przed kryzysem (lata 2007-2008), w trakcie trwania (lata 2009-2010) i przy wyjściu z kryzysu (lata 2011-2015) oraz łącznie dla całego okresu, czyli lat 2007-2015. Zioła i przyprawy stanowiły niewielki odsetek w eksporcie ogółem, więc miały mały wpływ na wolumen eksportu ogółem. Podobnie było w imporcie. Spośród państw z top 20 najwyższy był udział ziół i przypraw w eksporcie ogółem w Iranie (około 0,4\%), zaś w imporcie ogółem Arabii Saudyjskiej (około 0,1\%). Celem analizy było jednak sprawdzenie, czy zmiany zachodzą w podobnym kierunku, czy w wyniku kryzysu podobnie zmniejszał się eksport ogółem i w odniesieniu do ziół i przypraw. Podobnie W pracy starano się sprawdzić korelację, która nie wskazuje że dany czynnik wpływa na inny, tylko że istnieje między nimi silny lub słaby związek.

Tabela 4. Współczynniki korelacji między eksportem i importem ziół i przypraw na świecie i wybranymi parametrami

Table 4. The correlation coefficients between the export and import of herbs and spices in the world and selected parameters

\begin{tabular}{l|cccc}
\hline \multicolumn{1}{c|}{ Kraje } & \multicolumn{3}{c}{ Współczynniki korelacji liniowej Pearsona w latach } \\
& $2007-2008$ & $2009-2010$ & $2011-2015$ & $2007-2015$ \\
\hline Współczynniki korelacji między wartością eksportu a & & & 0,252 \\
wartością PKB & 0,069 & 0,171 & 0,310 & 0,001 \\
p-value & 0,672 & 0,291 & 0,002 & 0,478 \\
wartością eksportu ogółem & 0,266 & 0,417 & 0,535 & 0,001 \\
p-value & 0,097 & 0,007 & 0,001 & 0,354 \\
wartością importu ogółem & 0,150 & 0,300 & 0,001 \\
p-value & 0,356 & 0,060 & 0,411 & 0,728 \\
Współczynniki korelacji między wartością importu a & & 0,001 & 0,001 \\
wartością PKB & 0,819 & 0,797 & 0,730 & 0,701 \\
p-value & 0,001 & 0,001 & 0,001 & 0,001 \\
wartością eksportu ogółem & 0,722 & 0,733 & 0,709 & 0,747 \\
p-value & 0,001 & 0,001 & 0,001 & 0,001 \\
wartością importu ogółem & 0,828 & 0,813 & 0,745 & 0,001 \\
p-value & 0,001 & 0,001 & & \\
\hline
\end{tabular}

Źródło: jak na rys. 1.

Stwierdzono, że w przypadku eksportu ziół i przypraw, przed kryzysem i w trakcie jego trwania nie było związków $\mathrm{z}$ wybranymi wskaźnikami opisującymi sytuację gospodarczą. Jedynym wyjątkiem były relacje $\mathrm{z}$ eksportem ogółem $(\mathrm{r}=0,417$, pvalue $=0,007$ ). Najsilniejsze dodatnie związki wykazano $\mathrm{w}$ momencie wychodzenia $\mathrm{z}$ kryzysu w latach 2011-2015. Wysoka korelacja była wówczas w relacji wartości eksportu 
ziół i przypraw i eksportu ogółem $(\mathrm{r}=0,535, \mathrm{p}$-value $<0,001)$, zaś słaba dla wartości PKB $(\mathrm{r}=0,310, \mathrm{p}$-value $<0,002)$ i importu ogółem $(\mathrm{r}=0,411$, $\mathrm{p}$-value $<0,001)$.

$\mathrm{Na}$ podstawie zestawionych współczynników korelacji można stwierdzić, że istniał bardzo silny związek wartości importu ziół i przypraw z parametrami gospodarki określonymi przez wartość PKB, wartość eksportu i importu ogółem. Siła zależności była większa w okresie przed i w trakcie kryzysu niż po wyjściu z niego. Potwierdza to jeszcze bardziej zależności między następującymi zmianami w gospodarce i imporcie ziół. Podobne zależności stwierdzono przy analizie dokonanej przez Rokickiego i Wiluk (2016) dla państw UE za lata 2007-2013. Dobra koniunktura gospodarcza zachęcała do sprowadzania $\mathrm{z}$ innych krajów wielu ziół i przypraw, często niedostępnych na rynku wewnętrznym i bardzo drogich. Pogorszenie sytuacji gospodarczej oddziaływało na zmniejszenie obrotów w imporcie ziół i przypraw, które wówczas mogą stać się towarem luksusowym.

\section{Podsumowanie}

Wartość handlu zagranicznego ziołami i przyprawami na świecie w latach 2007-2015 zwiększyła się. Eksport i import były na podobnym poziomie. Saldo handlu ziołami i przyprawami na świecie w 2015 roku było ujemne - $153 \mathrm{mln}$ USD. Zdarzały się też lata, w których więcej ziół i przypraw eksportowano niż importowano. Stwierdzono różnice w dynamice zmian wartości handlu zagranicznego ziołami i przyprawami w latach 20072015. Należy pamiętać, że istnieje duża różnorodność ziół i przypraw oraz występują duże różnice $\mathrm{w}$ cenie jednostkowej. W pracy nie zbadano takich zależności z uwagi na brak ogólnie dostępnych danych. Największymi eksporterami i importerami ziół oraz przypraw były z reguły państwa o dużej powierzchni, zaś wyjątkiem od reguły była Holandia.

Występowała duża koncentracja w handlu, ale była ona większa w eksporcie niż imporcie. W przypadku eksportu stwierdzono, że w 2009 roku, w trakcie trwania kryzysu gospodarczego, zmniejszyła się sprzedaż ziół i przypraw na świecie, jednak w większości państw z top-20 eksport wzrósł. Przy imporcie sytuacja była bardziej stabilna, a jego wartość zwiększyła się w 2009 roku. W przypadku państw o największym handlu zmiany były gwałtowne w eksporcie, zaś umiarkowane w imporcie. Wśród mniejszych eksporterów i importerów ziół oraz przypraw zaobserwowano natomiast państwa o bardzo dużych wzrostach obrotów w poszczególnych latach, jak Peru i Portugali przy sprzedaży za granicę i Bangladesz przy imporcie.

Ostatnia część analizy polegała na ustaleniu związku między eksportem i importem ziół oraz przypraw w krajach $\mathrm{z}$ top-20 a wybranymi parametrami ich gospodarek. Stwierdzono bardzo silną, istotną, dodatnią zależność z badanymi parametrami gospodarki w przypadku wartości importu ziół i przypraw oraz przeciętną lub słabą dla wartości eksportu ziół i przypraw (ale tylko po wyjściu z kryzysu gospodarczego). Kryzys gospodarczy wpłynął na zmniejszenie siły związków importu ziół i przypraw ze zmianami w gospodarce oraz wzmocnienie relacji w przypadku eksportu ziół. Import ziół i przypraw, szczególnie tych drogich $\mathrm{w}$ okresie dekoniunktury był ograniczany, zaś wzrastał przy dobrej sytuacji gospodarczej. Eksport często był mniej zależny od koniunktury gospodarczej, a bardziej od wielkości zbiorów. Producenci ziół i przypraw musieli po prostu sprzedać wytworzone produkty na rynku krajowym lub zagranicznym, nawet mimo dekoniunktury gospodarczej. 


\section{Literatura}

Dane FAOSTAT, http://www.fao.org/faostat/en/\#data, Pobrano: maj 2017.

Departament Analizy Rynku UOKiK (2007). Raport z badania rynku przypraw w Polsce, Urząd Ochrony Konkurencji i Konsumentów.

Hołubowicz-Kliza, G. (2012). Polowa uprawa ziół. Puławy: Wydawnictwo IUNG-PIB.

Iwaniuk, A., (2006). Atlas ziół krajowych, Bellona, Warszawa.

Narodowy Bank Polski (2009). Polska wobec światowego kryzysu.

Nurzyńska-Wierdak, R. (2012). Ocimum basilicum L. - wartościowa roślina przyprawowa, lecznicza olejkodajna. Praca przeglądowa. Annales Universitatis Maria Curie-Skłodowska Lublin - Polonia, 22(1), 20-30.

Olewnicki, D., Jabłońska, L., Orliński, P., Gontar, Ł. (2015). Zmiany w krajowej produkcji zielarskiej i wybranych rodzajach przetwórstwa roślin zielarskich w kontekście globalnego wzrostu popytu na te produkty, ZN SGGW Problemy Rolnictwa Światowego, 15(1), 68-76.

Rokicki, T., Wiluk, M. (2016). Handel zagraniczny ziołami i przyprawami w krajach Unii Europejskiej, $Z N$ SGGW Problemy Rolnictwa Światowego, 16(2), 269-278.

Sadowski A., Kozłowska-Brudziak M. (2013). Produkcja ziół w województwie podlaskim i możliwości jej zwiększenia w ocenie rolników. Roczniki Naukowe Stowarzyszenia Ekonomistów Rolnictwa i Agrobiznesu, $15(1), 109-114$

Seidler-Łożykowska, K. (2009). Hodowla i odmiany roślin zielarskich. Hodowla roślin i nasiennictwo, Warszawa. Sederski, M. E. (2017). Prawie wszystko o ziołach i ziołolecznictwie, Wydawca Mateusz E. Senderki, Podkowa Leśna, 15-17.

Stelmach, W. (2017). Z historii przypraw, Świat Zdrowia, 4, 106.

Williams, P. (2006). Health benefits of herbs and spices. Publ. Health Medical Journal of Australia 185(4), 17-18. 